\title{
Copper changes the yield and cadmium/zinc accumulation and cellular distribution in the cadmium/zinc hyperaccumulator Sedum plumbizincicola
}

\author{
Zhu Li ${ }^{\mathrm{a}, \mathrm{b}}$, Longhua $\mathrm{Wu}^{\mathrm{a}, *}$, Pengjie $\mathrm{Hu}^{\mathrm{a}}$, Yongming Luo ${ }^{\mathrm{a}, \mathrm{c}}$, Peter Christie ${ }^{\mathrm{d}}$ \\ a Key Laboratory of Soil Environment and Pollution Remediation, Institute of Soil Science, Chinese Academy of Sciences, Nanjing 210008 , China \\ ${ }^{\mathrm{b}}$ University of the Chinese Academy of Sciences, Beijing 100049, China \\ ${ }^{c}$ Yantai Institute of Coastal Zone Research, Yantai 264003, China \\ d Agri-Environment Branch, Agri-Food and Biosciences Institute, Newforge Lane, Belfast BT9 5PX, UK
}

\section{H I G H L I G H T S}

- Low Cu has no significant effect on Sedum plumbizincicola plant growth and Cd and $\mathrm{Zn}$ uptake.

- Plant held $\mathrm{Cu}$ in unactive areas and insoluble forms as de-toxification mechanisms.

- Influence of $\mathrm{Cu}$ on $\mathrm{Zn}$ and $\mathrm{Cd}$ uptake and translocation were different.

- $\mathrm{Cu}$ accumulation in leaf veins may restrain $\mathrm{Cd} / \mathrm{Zn}$ unloading to the leaves

\section{A R T I C L E I N F O}

\section{Article history:}

Received 10 January 2013

Received in revised form 15 July 2013

Accepted 25 July 2013

Available online 1 August 2013

\section{Keywords:}

Metal toxicity

Interactions

Hyperaccumulation

Translocation

$\mu$-SXRF

\begin{abstract}
A B S T R A C T
Non-accumulated metals in mixed metal contaminated soils may affect hyperaccumulator growth and metal accumulation and thus remediation efficiency. Two hydroponics experiments were conducted to investigate the effects of copper $(\mathrm{Cu})$ on cadmium $(\mathrm{Cd})$ and zinc $(\mathrm{Zn})$ accumulation by the $\mathrm{Cd} / \mathrm{Zn}$ hyperaccumulator Sedum plumbizincicola, $\mathrm{Cu}$ toxicity and plant detoxification using chemical sequential extraction of metals, sub-cellular separation, micro synchrotron radiation based X-ray fluorescence, and transmission electron microscopy. Compared with the control $(0.31 \mu \mathrm{M} \mathrm{Cu}), 5-50 \mu \mathrm{M} \mathrm{Cu}$ had no significant effect on $\mathrm{Cd} / \mathrm{Zn}$ accumulation, but $\mathrm{Cu}$ at $200 \mu \mathrm{M}$ induced root cell plasmolysis and disordered chloroplast structure. The plants held $\mathrm{Cu}$ in the roots and cell walls and complexed $\mathrm{Cu}$ in insoluble forms as their main detoxification mechanisms. Exposure to $200 \mu \mathrm{M}$ Cu for 4 days inhibited plant $\mathrm{Cd}$ uptake and translocation but did not affect $\mathrm{Zn}$ concentrations in roots and stems. Moreover, unloading of $\mathrm{Cd}$ and $\mathrm{Zn}$ from stem to leaf was restrained compared to control plants, perhaps due to $\mathrm{Cu}$ accumulation in leaf veins. Copper may thus interfere with root $\mathrm{Cd}$ uptake and restrain $\mathrm{Cd} / \mathrm{Zn}$ unloading to the leaves. Further investigation of how $\mathrm{Cu}$ affects plant metal uptake may help elucidate the $\mathrm{Cd} / \mathrm{Zn}$ hyper-accumulating mechanisms of S. plumbizincicola.
\end{abstract}

(C) 2013 Elsevier B.V. All rights reserved.

\section{Introduction}

Mixed and multiple contamination of soils by metals can result from industrial and mining activities and agricultural practices such as land application of contaminated sewage sludges and usually involves several contaminants [1,2]. Phytoremediation using hyperaccumulator plants to remove contaminants from soils is an environmentally friendly and relatively inexpensive technique [3-5]. However, most hyperaccumulators can typically remediate

\footnotetext{
* Corresponding author. Tel.: +86 2586881128.

E-mail address: lhwu@issas.ac.cn (L.Wu).
}

only a very limited number of pollutants so that other nonaccumulated metals (i.e. metals the hyperaccumulator does not have the ability to hyperaccumulate) remaining in the soil may affect the growth, metal accumulation, and hence phytoremediation efficiency of the hyperaccumulator.

There are several published studies on the influence of metal interactions on hyperaccumulators. For example, Ni was found to affect $\mathrm{Cu}$ and Fe homeostasis in the Ni-hyperaccumulator Alyssum inflatum [6] and $\mathrm{Cu}, \mathrm{Mn}$ and $\mathrm{Zn}$ affected the Mn-hyperaccumulator Phytolacca americana [7], with Mn interacting with Cd in the same plant species [8]. Cadmium and $\mathrm{Zn}$ interactions occurred during uptake, translocation and subcellular distribution in the hyperaccumulators Potentilla griffithii, Thlaspi caerulescens, and Arabidopsis 
halleri [9-11]. There have been few reports on the effects of $\mathrm{Cu}$ on hyperaccumulators and their metal accumulation. Copper is an essential element for plant growth through its role in the composition of many enzymes and proteins, but the normal range of $\mathrm{Cu}$ concentrations in plants is very narrow (5-20 $\mathrm{mg} \mathrm{kg}^{-1}$ ) [12] and high $\mathrm{Cu}$ concentrations in the growth medium might induce phytotoxicity by interacting with other essential elements, impairing cells through oxidative damage, disrupting the structure of proteins, and inactivating some key enzymes [13]. Metal toxicity to plant can be reflected by plant apparent characters (e.g. plant biomass) and the change of cell and organelles which can be characterized by ultra-structure of cell (transmission electron micrographs) [14]. As metal distribution in different cell parts and different metal chemical forms have different toxicity to plant, metal in cellular distribution and chemical forms can be used to investigate plant detoxification mechanisms [15]. Sedum plumbizincicola, a Cd/Zn hyperaccumulator with large biomass and high accumulation of $\mathrm{Cd} / \mathrm{Zn}$ in the shoots [16,17], is a promising species for the remediation $\mathrm{Cd} / \mathrm{Zn}$ polluted soils. However, this species was found to have a very high Cu concentration $\left(254 \mathrm{mg} \mathrm{kg}^{-1}\right)$ in shoots and its growth was significantly inhibited when plant grow in acid soil (pH, 4.56; total $\mathrm{Cu}$ in soil, $\left.369 \mathrm{mg} \mathrm{kg}^{-1}\right)$ [18]. Also $688 \mathrm{mg} \mathrm{kg}^{-1}$ $\mathrm{Cu}$ was detected in S. plumbizincicola when EDDS was applied to enhance Cd and Zn phytoextraction in an alkaline soil [19]. It is therefore necessary to investigate the potential effects of $\mathrm{Cu}$ on $\mathrm{S}$. plumbizincicola and its accumulation of $\mathrm{Cd}$ and $\mathrm{Zn}$ for the potential phytoremediation in $\mathrm{Cd} / \mathrm{Zn}$ and $\mathrm{Cu}$ co-polluted soils.

In the present study, two hydroponics experiments were conducted and the methods employed included chemical sequential extraction of plant metals and subcellular separation based on differential centrifugation, micro synchrotron radiation based X-ray fluorescence ( $\mu$-SXRF) and transmission electron microscopy of plant samples. The aims were to determine how $\mathrm{Cu}$ influences $\mathrm{Cd}$ and $\mathrm{Zn}$ uptake and accumulation by S. plumbizincicola and to investigate the possibility of $\mathrm{Cu}$ toxicity and plant detoxification.

\section{Materials and methods}

\subsection{Hydroponics experiments}

\subsubsection{Plant preparation}

S. plumbizincicola shoots were collected from a seedbed of $S$. plumbizincicola in a field experimental facility (located in the suburbs of Hangzhou city, Zhejiang province, east China), cut into uniform pieces and washed with tap water, and then a plastic pot $(10 \mathrm{~L})$ was used to culture the plant shoots using fresh nutrient solution. The solution was modified Hoagland nutrient solution: $\mathrm{Ca}\left(\mathrm{NO}_{3}\right)_{2} \cdot 4 \mathrm{H}_{2} \mathrm{O} 1.0, \mathrm{MgSO}_{4} \cdot 7 \mathrm{H}_{2} \mathrm{O} 0.5, \mathrm{~K}_{2} \mathrm{HPO}_{4} 0.5$, KCl 0.1 , MES 1.0 , and $\mathrm{KOH} 0.5 \mathrm{mmol} \mathrm{L}^{-1}$; and $\mathrm{H}_{3} \mathrm{BO}_{3} 10, \mathrm{Na}_{2} \mathrm{MoO}_{4} \cdot 2 \mathrm{H}_{2} \mathrm{O} 0.2$, $\mathrm{MnSO}_{4} \cdot 4 \mathrm{H}_{2} \mathrm{O} 1.8, \mathrm{CuSO}_{4} \cdot 5 \mathrm{H}_{2} \mathrm{O} 0.31, \mathrm{NiSO}_{4} \cdot 6 \mathrm{H}_{2} \mathrm{O} 0.5$, Fe-EDDHA 100 , and $\mathrm{ZnSO}_{4} \cdot 7 \mathrm{H}_{2} \mathrm{O} 5 \mu \mathrm{mol} \mathrm{L}^{-1}$. The replacement of EDTA with EDDHA is because EDDHA has higher complex ability with iron than EDTA, which resulting high available iron for plant [20]. The $\mathrm{pH}$ value was adjusted to 5.8 with $0.1 \mathrm{M}$ sodium hydroxide $(\mathrm{NaOH})$ and/or $0.1 \mathrm{M}$ hydrochloric acid $(\mathrm{HCl})$ and the solution was continuously aerated with a pump during plant growth. The solution was replaced with fresh medium every three days. The plants grew in a growth chamber with a day/night temperature regime of $25 / 20^{\circ} \mathrm{C}$ and a photoperiod of $14 \mathrm{~h}$ at a photosynthetically active radiation flux of $60 \mathrm{w} \mathrm{m}^{-2}$. The plant shoots produced roots after two weeks and healthy looking plants of uniform size were chosen for the hydroponics experiments. One sample was separated into leaf, stem and root and the plant parts were washed with double distilled water and dried at $80^{\circ} \mathrm{C}$ prior to determination of the metal concentrations before the experiments began.

\subsubsection{Experiment 1: plant treatment with $\mathrm{Cu}, \mathrm{Zn}$ and $\mathrm{Cd}$}

The prepared plants were transferred to 2 -L plastic containers with polystyrene covers, each with 6 evenly spaced holes and 1 smaller hole in the center. Before plants were transferred to 2-L plastic containers, six levels of $\mathrm{Cu}$ as $\mathrm{CuSO}_{4} \cdot 5 \mathrm{H}_{2} \mathrm{O}$, i.e. 0.31 (control, the $\mathrm{Cu}$ concentration in the nutrient solution), 5, 10, 50, 100, $200 \mu \mathrm{M}$ for each pot, and $50 \mu \mathrm{M} \mathrm{Cd}$ and $500 \mu \mathrm{M} \mathrm{Zn}$ (as the nitrates) for all pots were also added to the nutrient solution and the $\mathrm{pH}$ was adjusted to about 5.8 with $0.1 \mathrm{M} \mathrm{NaOH}$ and/or $0.1 \mathrm{M} \mathrm{HCl}$. There were six plants in each pot and four replicates of each treatment were randomly arranged on a bench inside the growth chamber and the conditions were the same as described above for plant preparation. Fourteen days after the plants were exposed to the $\mathrm{Cu}$ the plants exposed to 100 or $200 \mu \mathrm{M}$ Cu displayed visual toxicity symptoms and all plants were harvested. The roots were soaked in $20 \mathrm{mmol} \mathrm{L}^{-1}$ EDTA solution for $30 \mathrm{~min}$ and rinsed with distilled water. Each plant sample was divided into leaves, stems and roots and all plant parts were washed thoroughly with distilled water and then oven dried at $80^{\circ} \mathrm{C}$.

\subsubsection{Experiment 2: plant treatment with $\mathrm{Cu}, \mathrm{Zn}$ and $\mathrm{Cd}$ for short time}

In hydroponics experiment 1 S. plumbizincicola showed toxicity symptoms under high $\mathrm{Cu}(200 \mu \mathrm{M})$. In experiment $2,0.31 \mu \mathrm{M}$ and $200 \mu \mathrm{M}$ Cu were selected together with $50 \mu \mathrm{M}$ Cd and $500 \mu \mathrm{MZn}$ to test the further metal effects. Each treatment had four replicates, and there were six plants in each pot and the growth conditions were the same as described above for plant preparation. After the metals were added to the nutrient solution the $\mathrm{pH}$ was adjusted as descibed above for experiment 1 . Four days after the metals were added to the nutrient solution the experiment was ended because plants in the high $\mathrm{Cu}$ treatment showed clear toxicity symptoms and the roots secreted copious white material. After the roots were soaked in a solution of $20 \mathrm{mmol} \mathrm{L}^{-1}$ EDTA for $30 \mathrm{~min}$ the plant samples were separated into leaves, stems and roots. All plant samples were rinsed thoroughly with distilled water and dried with paper tissue. The fresh samples were prepared for transmission electron microscopy and $\mu$-SXRF (details below) and then 2.00g sub-samples (cut into 1-2 mm pieces) were weighed accurately and stored at $-20^{\circ} \mathrm{C}$ for metal sequential extraction and plant tissue separation. The remainder of each sample was oven dried at $80^{\circ} \mathrm{C}$.

\subsection{Sequential extraction of metals}

Sequential extraction of $\mathrm{Cu}, \mathrm{Cd}$ and $\mathrm{Zn}$ in plants was conducted by the methods of Wang et al. [15] and $\mathrm{Wu}$ et al. [21]. Metals in plants were divided into six chemical forms according to the different extractant solutions in the following order: (1) $80 \%$ ethanol, extracting the inorganic metal fraction including metalnitrate, chloride and aminophenol; (2) distilled water, extracting the water soluble fraction including metal complexed with organic acids and $\mathrm{M}\left(\mathrm{H}_{2} \mathrm{PO}_{4}\right)_{2}$; (3) $1 \mathrm{M} \mathrm{NaCl}$, extracting metals associated with pectates and proteins; (4) $2 \%$ acetic acid (HAC), extracting the insoluble metal fraction including $\mathrm{MHPO}_{4}$ and $\mathrm{M}_{3}\left(\mathrm{PO}_{4}\right)_{2} ;(5) 0.6 \mathrm{M}$ $\mathrm{HCl}$, extracting M-oxalate; and (6) metal in residues. The frozen plant leaf, stem and root tissues with a fresh weight of $2.00 \mathrm{~g}$ were homogenized in extractant solution with a glass mortar and pestle, diluted at a ratio of $1: 10(\mathrm{w} / \mathrm{v})$, and shaken for $22 \mathrm{~h}$ at $25^{\circ} \mathrm{C}$. The homogenate was centrifuged (Nr. 12150-H, Sigma, Osterode am Harz, Germany) at $5000 \times \mathrm{g}$ for $10 \mathrm{~min}$ and the supernatant was carefully transferred to a $100 \mathrm{ml}$ flask. The pellet was re-suspended twice in the same extractant solution and shaken for $2 \mathrm{~h}$ at $25^{\circ} \mathrm{C}$, centrifuged at $5000 \times g$ for $10 \mathrm{~min}$, and the three supernatants were pooled. The pooled supernatant solutions from each fraction and 
the residual fractions were then evaporated at $70^{\circ} \mathrm{C}$ to nearly constant weight prior to digestion.

\subsection{Plant tissue separation}

Differential centrifugation was used to separate plant tissues following the methods of Wu et al. [21] and Weigel and Jäeger [22]. The frozen plant leaf, stem and root tissues with a fresh weight of $2.00 \mathrm{~g}$ were homogenized in pre-cooled extraction buffer $(200 \mathrm{mM}$ sucrose, $50 \mathrm{mM}$ Tris- $\mathrm{HCl}, 1.0 \mathrm{mM}$ DET $\left(\mathrm{C}_{4} \mathrm{H}_{10} \mathrm{O}_{2} \mathrm{~S}_{2}\right), 5.0 \mathrm{mM}$ ascorbic acid and $1.0 \%(\mathrm{w}: \mathrm{v})$ Polyclar AT PVPP, $\mathrm{pH} 7.5$ ) with a chilled glass mortar and pestle. The homogenate was transferred to a $50 \mathrm{ml}$ centrifuge tube for separation. The first centrifugation (Nr. $12150-\mathrm{H}$, Sigma, Osterode am Harz, Germany) was at $300 \times g$ for $30 \mathrm{~s}$ and the pellet was defined as F1 containing mainly cell walls and cell wall debris; the second at $1500 \times g$ for $15 \mathrm{~min}$ (root samples at $2500 \times g$ for $20 \mathrm{~min}$ ) and the pellet was regarded as F2 containing chloroplasts from leaves and shoots or trophoplasts from roots; and finally at $15,000 \times \mathrm{g}$ for $35 \mathrm{~min}$ and the pellet was membranes and organelles defined as F3, and the supernatant was considered to be the soluble fraction, F4. All the above steps were performed at $4{ }^{\circ} \mathrm{C}$. The pellets obtained at each centrifugation step were resuspended in a glass flask and dried to nearly constant weight at $70^{\circ} \mathrm{C}$ and digested by the method described below for whole plant samples.

\section{4. $\mu$-SXRF spectroscopy data collection}

The $\mu$-SXRF data were collected on beam line $15 \mathrm{U}$ (3.5 GeV and $300 \mathrm{~mA}$ ) at Shanghai Synchrotron Radiation Facility. The sample was oriented $45^{\circ}$ to the incident X-ray beam. Fluorescence signals were collected using a Si (III) solid-state multi-element detector. The beam energy was set to $11 \mathrm{keV}$ to detect the elements in samples and the fluorescence maps were collected with a beam size $2 \times 2 \mu \mathrm{m}^{2}$ using a step size of $10 \mu \mathrm{m} \times 12 \mu \mathrm{m}$ at a integration time of $100 \mathrm{~ms}$. The samples were prepared as follows. The fifth (from top) well developed leaf in hydroponics experiment 2 was selected and the surface was rinsed with d-water. The leaves were cut into pieces with a razor blade and cryofixed by a freezing method with liquid nitrogen $\left(\mathrm{LN}_{2}\right)$. The cryofixed leaf samples were transferred into $5 \mathrm{ml}$ plastic vials with a hole in the cover and then dried in an Emitech K750 Freeze Drier (Ashford, Kent, UK) at $-60^{\circ} \mathrm{C}$ at a pressure of 0.02 mbar for 3 days. The freeze-dried leaf samples were hand sectioned using unused and cleaned razor blades and placed on an adhesive tape for detection.

\subsection{Transmission electron microscopy}

The fifth well-developed leaf (from the plant top) and root tips were selected as detection samples. Small sections of samples $1-2 \mathrm{~mm}^{2}$ in area (leaf) or $1-3 \mathrm{~mm}$ long (root) were cut and fixed in $6 \%$ glutaraldehyde $(\mathrm{v} / \mathrm{v})$ in $0.2 \mathrm{M}$ sodium phosphate buffer ( $\mathrm{pH} 7.2$ ) for $10 \mathrm{~h}$ and post-fixed in $2 \% \mathrm{OsO}_{4}$ for $1 \mathrm{~h}$. The dehydration samples used graded ethanol with concentration series: 50 , $60,70,80,90,95$ and $100 \%$ and acetone; then samples were infiltrated and embedded in ethoxy resin (E-pon812). Ultrathin sections $(70 \mathrm{~nm})$ were prepared and placed on copper grids for viewing in the transmission electron microscope (Hitachi H-7650, Japan).

\subsection{Determination of metals in plant and soil samples}

Dry plant samples $(\sim 0.25 \mathrm{~g} \mathrm{DM})$ and the residues from the sequential extraction were digested with a mixture of $6 \mathrm{ml} \mathrm{HNO}$ and $4 \mathrm{ml} \mathrm{HClO}_{4}$. Digestion solutions were determined for $\mathrm{Cd}, \mathrm{Zn}$ and $\mathrm{Cu}$ using AAS (Varian SpectrAA $220 \mathrm{FS}$ ). A certified reference material (GBW07603, provided by the Institute of Geophysical and
Table 1

Biomass of leaves, stems and roots of S. plumbizincicola exposed to different $\mathrm{Cu}$ concentrations in the nutrient solution for 14 days $\left(\mathrm{g} \mathrm{pot}^{-1}\right)$. Data presented are mean \pm standard error $(n=4)$. Different letters in a column indicate significant difference from each other $(P<0.05)$.

\begin{tabular}{clll}
\hline Cu in solution $(\mu \mathrm{M})$ & Leaf & Stem & Root \\
\hline 0.31 & $0.61 \pm 0.06 \mathrm{a}$ & $0.34 \pm 0.04 \mathrm{a}$ & $0.22 \pm 0.02 \mathrm{a}$ \\
5 & $0.72 \pm 0.07 \mathrm{a}$ & $0.44 \pm 0.04 \mathrm{a}$ & $0.28 \pm 0.04 \mathrm{a}$ \\
10 & $0.69 \pm 0.06 \mathrm{a}$ & $0.39 \pm 0.04 \mathrm{a}$ & $0.20 \pm 0.06 \mathrm{a}$ \\
50 & $0.70 \pm 0.13 \mathrm{a}$ & $0.41 \pm 0.06 \mathrm{a}$ & $0.30 \pm 0.06 \mathrm{a}$ \\
100 & $0.43 \pm 0.02 \mathrm{~b}$ & $0.27 \pm 0.03 \mathrm{a}$ & $0.23 \pm 0.02 \mathrm{a}$ \\
200 & $0.36 \pm 0.02 \mathrm{~b}$ & $0.31 \pm 0.04 \mathrm{a}$ & $0.22 \pm 0.02 \mathrm{a}$ \\
\hline
\end{tabular}

Geochemical Exploration, Langfang, Hebei Province, China) was used for quality control. The data obtained by the methods above were within the certified ranges for $\mathrm{Cu}, \mathrm{Zn}$ and $\mathrm{Cd}$.

\subsection{Statistical analysis}

Data were presented as mean \pm standard error of the mean and were analyzed by one-way analysis of variance using SPSS version 16.0 for Windows. Differences in mean shoot biomass or metal concentrations between treatments were tested by Duncan's multiple range test at the $5 \%$ level. The maps of $\mu$-SXRF were made with Igor Pro 6.10A and other figures with Microsoft Excel 2003 or Origin 8.0.

\section{Results}

\subsection{Plant biomass and metal concentrations under different $\mathrm{Cu}$ treatments}

The $\mathrm{Cu}$ in the nutrient solution exerted a significant influence on the growth of S. plumbizincicola exposed to different levels of $\mathrm{Cu}$ for 14 days (Table 1$)$. Compared to the control $(0.31 \mu \mathrm{M} \mathrm{Cu})$ the average leaf biomass in the $5-50 \mu \mathrm{M} \mathrm{Cu}$ treatments did not increase significantly. However, when the solution $\mathrm{Cu}$ concentration was $100 \mu \mathrm{M}$ or $200 \mu \mathrm{M}$ the plants exhibited growth inhibition and the leaf biomass was significantly lower than the control (Table 1). However, in experiment 2 the plants were exposed to the same $\mathrm{Cu}$ concentrations for only 4 days and there was no significant difference in biomass (data not shown), possibly due to the short exposure time.

Plant metal concentrations after $14 \mathrm{~d}$ exposure to different levels of $\mathrm{Cu}$ (from 0.31 to $200 \mu \mathrm{M}$ ) at the same $\mathrm{Cd}(50 \mu \mathrm{M})$ and $\mathrm{Zn}$ $(500 \mu \mathrm{M})$ levels in experiment 1 are shown in Fig. 1. Leaf, stem, and root $\mathrm{Cu}$ concentrations increased linearly with increasing $\mathrm{Cu}$ concentration in the nutrient solution and the rate of increase in roots was much higher than in stems and leaves (Fig. 1A) and most of the $\mathrm{Cu}$ was accumulated in the roots. There was no significant difference among treatments $0.31-50 \mu \mathrm{M} \mathrm{Cu}$ in $\mathrm{Cd}$ in the leaf, stem and root, but a clear decline was found when the $\mathrm{Cu}$ concentration increased to 100 or $200 \mu \mathrm{M}$ (Fig. 1B). Zn showed similar trends to $\mathrm{Cd}$. Compared with control 5-50 $\mu \mathrm{M} \mathrm{Cu}$ levels in the solution produced no significant effect on the $\mathrm{Zn}$ concentrations in leaf, stem or root but 100 or $200 \mu \mathrm{M}$ Cu produced significantly lower leaf and stem $\mathrm{Zn}$ concentrations compared to the other treatments, but no significant change in the root (Fig. 1C).

In experiment 2, $200 \mu \mathrm{M} \mathrm{Cu}$ also depressed plant Cd accumulation compared to the control when the plants were exposed to the $\mathrm{Cu}$ for only 4 days. As with $\mathrm{Zn}, 200 \mu \mathrm{M}$ Cu did not show any significant influence on the $\mathrm{Zn}$ concentration in stems or roots compared with the control (Fig. 2), but inhibited leaf Zn uptake. Neither Cd nor $\mathrm{Zn}$ in the leaves in $200 \mu \mathrm{M}$ Cu treatment showed any significant difference from the control (Fig. 2). 

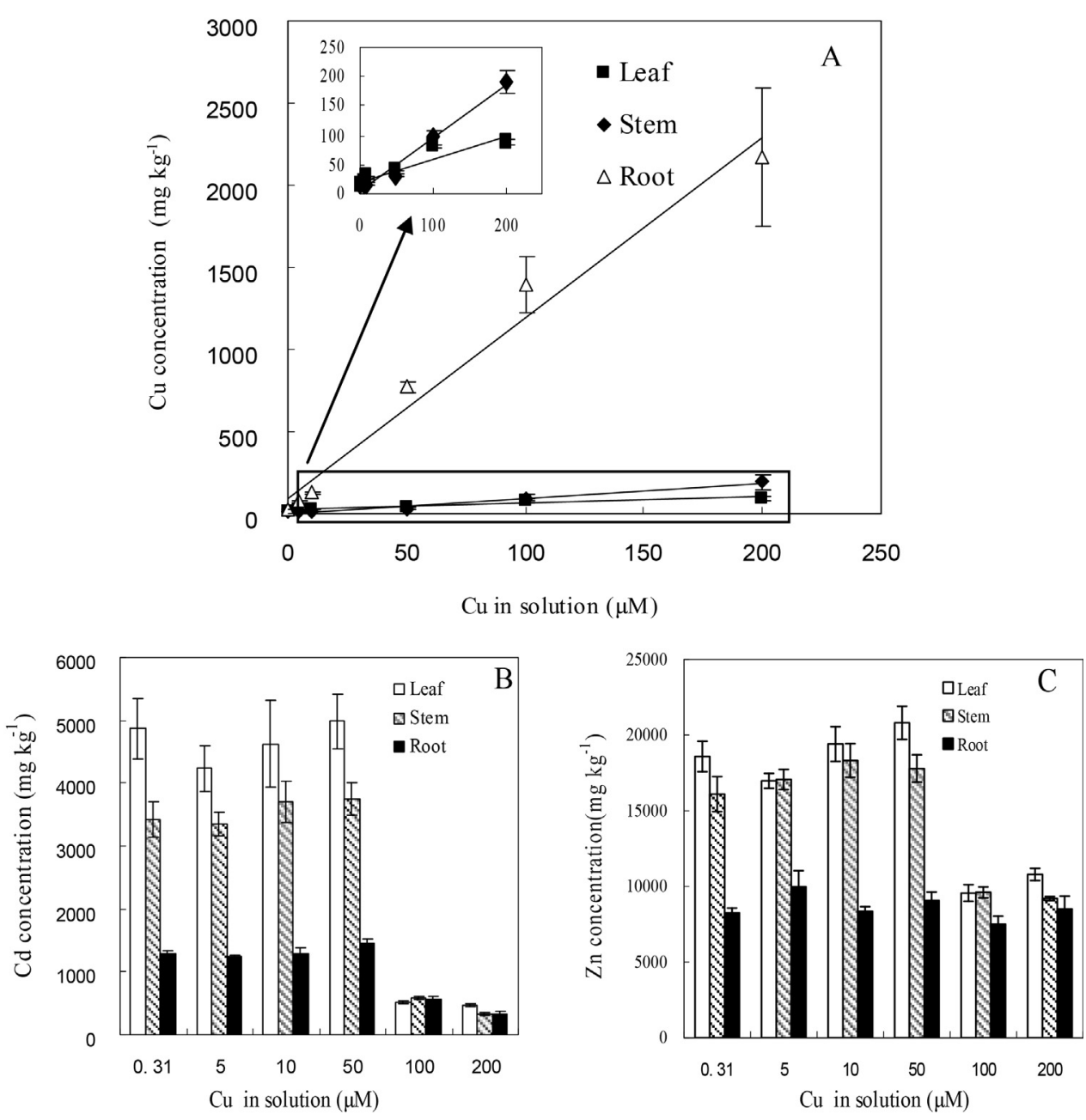

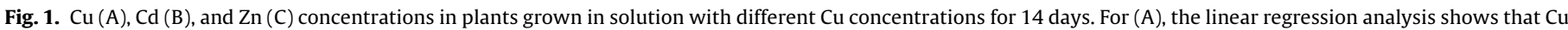

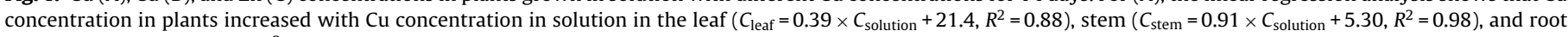
$\left(C_{\text {root }}=11.0 \times C_{\text {solution }}+88.4, R^{2}=0.98\right)$. Data presented are mean \pm standard error $(n=4)$.

\subsection{Effects of $\mathrm{Cu}$ on chemical forms of metals in the plant}

The chemical forms of $\mathrm{Cu}, \mathrm{Cd}$ and $\mathrm{Zn}$ in S. plumbizincicola in hydroponics experiment 2 are shown in Fig. 3.

$\mathrm{Cu}$ extracted by $80 \%$ ethanol was the dominant fraction in the leaves followed by $0.6 \mathrm{M} \mathrm{HCl}$, and there were no significant differences between the other fractions in the control. $200 \mu \mathrm{M} \mathrm{Cu}$ induced significant increase in the fractions extracted by distilled water and $2 \%$ HAc. There was no difference between the different chemical forms in the stems except for the lower fraction extracted by $1 \mathrm{M} \mathrm{NaCl}$ in the control. $\% \mathrm{HAc}$ extractable fractions were dominant followed by distilled water and $80 \%$ ethanol in the $200 \mu \mathrm{M} \mathrm{Cu}$ treatment. Compared to the control, these three fractions increased markedly and other forms increased slightly, but the residual fraction showed no apparent change. In terms of the percentage of the total, the fraction extracted by $2 \%$ HAc also increased greatly, from $13.5 \%$ in the control to $36.8 \%$ in the $200 \mu \mathrm{M}$ Cu treatment on average. Similar to the stems, $200 \mu \mathrm{M} \mathrm{Cu}$ induced significant increases in the first five $\mathrm{Cu}$ chemical forms in roots with respect to the control. The form extracted by $2 \%$ HAc showed the largest increase in percentage of the total from $7.07 \%$ (control) to $24.2 \%(200 \mu \mathrm{M} \mathrm{Cu})$ on average. However, the dominant chemical form of $\mathrm{Cu}$ was still the fraction extracted by $0.6 \mathrm{M} \mathrm{HCl}$ in both $\mathrm{Cu}$ treatments.

The distribution of Cd chemical forms in S. plumbizincicola differed from $\mathrm{Cu}$. Plant $\mathrm{Cd}$ consisted mainly of the forms extracted by
$80 \%$ ethanol, d-water and $1 \mathrm{M} \mathrm{NaCl}$, representing $88-98 \%$ of the total Cd in all plant organs, and other Cd chemical fractions were very low (Fig. 3 center). In leaves and stems $80 \%$ ethanol and $1 \mathrm{M} \mathrm{NaCl}$ extractable fractions dominated followed by d-water extractable, but in the roots the Cd extracted by $1 \mathrm{M} \mathrm{NaCl}$ was dominant at $>60 \%$ of the total Cd. Although $200 \mu \mathrm{M}$ Cu greatly and significantly lowered the concentration of $\mathrm{Cd}$ in the main chemical forms (the first three), their percentages of total Cd showed no marked change with respect to the control.

In common with $\mathrm{Cd}$, plant $\mathrm{Zn}$ mainly consisted of the forms extracted by $80 \%$ ethanol, d-water and $1 \mathrm{M} \mathrm{NaCl}$, representing 92-97\% of the total Cd in all plant organs of both treatments. Although $200 \mu \mathrm{M}$ Cu had no significant influence on the quantities of $\mathrm{Zn}$ chemical forms, a decrease on average in $\mathrm{Zn}$ extracted by $80 \%$ ethanol in stems and roots was observed. $200 \mu \mathrm{M} \mathrm{Cu}$ appeared to decrease the first four chemical fractions in the leaves but the apparent trend was not significant (Fig. 3 bottom).

\subsection{Effects of $\mathrm{Cu}$ on plant elemental distributions by differential centrifugation and $\mu$-SXRF}

The subcellular tissues of $S$. plumbizincicola were obtained by differential centrifugation and the corresponding percentages of metal concentrations in each fraction to the total are shown in Fig. 4. The percentage $\mathrm{Cu}$ in each fraction of total $\mathrm{Cu}$ in the leaves 

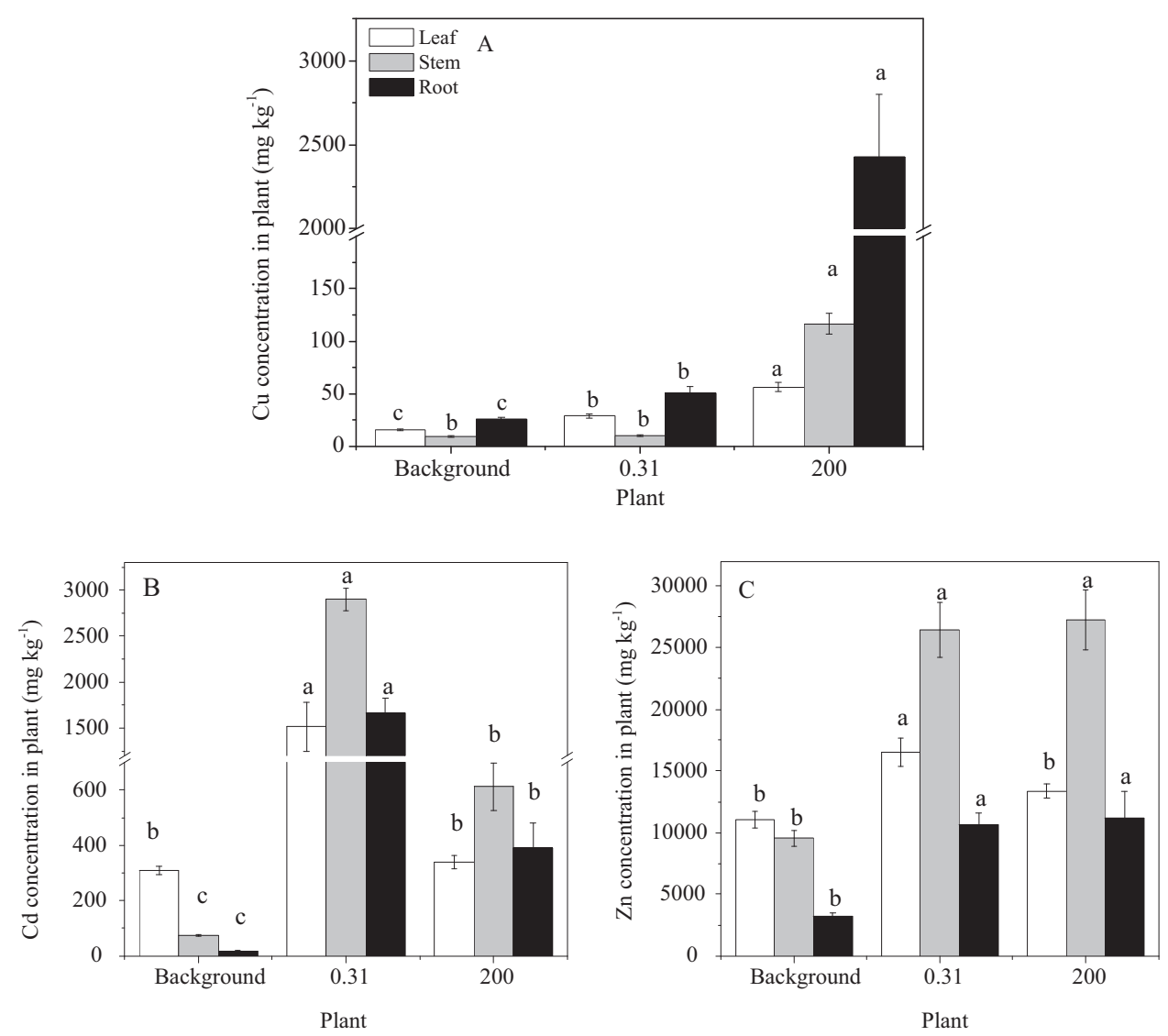

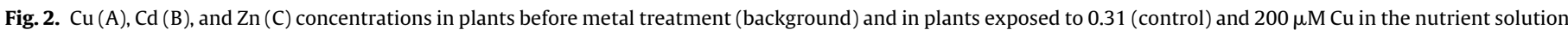
for 4 days. Different letters in plant parts indicate significant difference from each other $(P<0.05)$. Data presented are mean \pm standard error $(n=4)$.

did not change $(P>0.05)$ compared to the control. However fraction F1 in the stems increased by $10 \%$ and F2 decreased by $9 \%$. In the roots the $\mathrm{Cu}$ percentage in $\mathrm{F} 1$ increased by $7 \%$ increase and in $\mathrm{F} 4$ decreased by $6 \%$. The proportion of $\mathrm{Cd}$ in the $\mathrm{F} 1$ fraction in the of the leaves and roots in $200 \mu \mathrm{M}$ treatment increased by about 12 and 7\% and in fraction F4 decreased by 5 and $8 \%$, respectively. However, the percentage of $\mathrm{Cd}$ in all fractions in the stems did not change $(P>0.05)$. There was much more $\mathrm{Zn}$ accumulation in fraction F1 and less in fraction F4 in the leaves in the $200 \mu \mathrm{M}$ $\mathrm{Cu}$ treatment than in the control, with a $12 \%$ increase and $10 \%$ decrease respectively. In stems and roots in the $200 \mu \mathrm{M}$ Cu treatment the $\mathrm{Zn}$ percentage distributions increased slightly in fraction F1 with respective to the control, by $8 \%$ and $5 \%$ respectively, and changes in the other fractions in stems and roots were less than $5 \%$.

The effects of $\mathrm{Cu}$ on elemental distributions in leaves were also investigated by $\mu$-synchrotron $\mathrm{XRF}$, and the $\mathrm{Cu}, \mathrm{Zn}, \mathrm{P}$, and $\mathrm{K}$ distribution maps in the scanned area of leaf cross-sections of both levels of $\mathrm{Cu}$ treatment are shown in Fig. 5 together with the optical micrographs. Cd distribution would have been affected by interference from $\mathrm{K}$ and the results are not shown here. The X-ray fluorescence intensities are shown with different colors, from purple (maximum) to red (minimum) for the individual elements. Each map showed the relative distribution of elements and the count scales were set same for the same element in both Cu treatments. In the control $\mathrm{Cu}$ and $\mathrm{Zn}$ accumulated mainly in the leaf margins and epidermis and were evenly distributed in other regions. K distribution was concentrated in the leaf veins together with other peaks in the leaf margin and the epidermis. P was evenly distributed within the leaf cross-section. In the $200 \mu \mathrm{M}$ Cu treatment, $\mathrm{Cu}$ was concentrated mainly in the leaf veins and was also distributed in the leaf margin and upper epidermis. Zn occurred mainly in the leaf margin and epidermis. $\mathrm{K}$ showed a similar distribution to $\mathrm{Cu}$, mostly at the leaf veins. P was evenly located within the leaf cross-section as in the control. Comparing two treatment images indicated that the leaf cross-section in the $200 \mu \mathrm{M}$ Cu treatment had lower accumulation of $\mathrm{P}, \mathrm{K}$, and $\mathrm{Zn}$ and higher was in $\mathrm{Cu}$ than the control.

\subsection{Effects of $\mathrm{Cu}$ on ultra-structure of leaves and roots of $S$. plumbizincicola}

The transmission electron micrographs of leaf (Fig. 6A and B) and root (Fig. 6C and D) cells of S. plumbizincicola exposed to $0.31 \mu \mathrm{M}$ (Fig. 6A and C) and $200 \mu \mathrm{M} \mathrm{Cu}$ (Fig. 6B and D) showed that rare organelles occurred in the mesophyll cells of both two treatments, with only chloroplasts and mitochondria observed (Fig. 6A and B). After 4 days, the plants exposed to $200 \mu \mathrm{M}$ Cu showed clear differences in the chloroplasts compared to the control. In the control one or two large starch grains were present in the chloroplasts and the thylakoids were orderly, loosely and densely arranged. However, in the $200 \mu \mathrm{M}$ Cu treatment the chloroplasts had small starch grains and the thylakoids were disordered. Transmission electron micrographs of cells of the root tip show that copious organelles were present in the cytoplasm (Fig. 6C and D). Compared to the control the organelles in S. plumbizincicola roots in the $200 \mu \mathrm{M} \mathrm{Cu}$ treatment showed no visible damage but clear incipient plasmolysis was observed. Moreover, some particles were found regularly deposited 

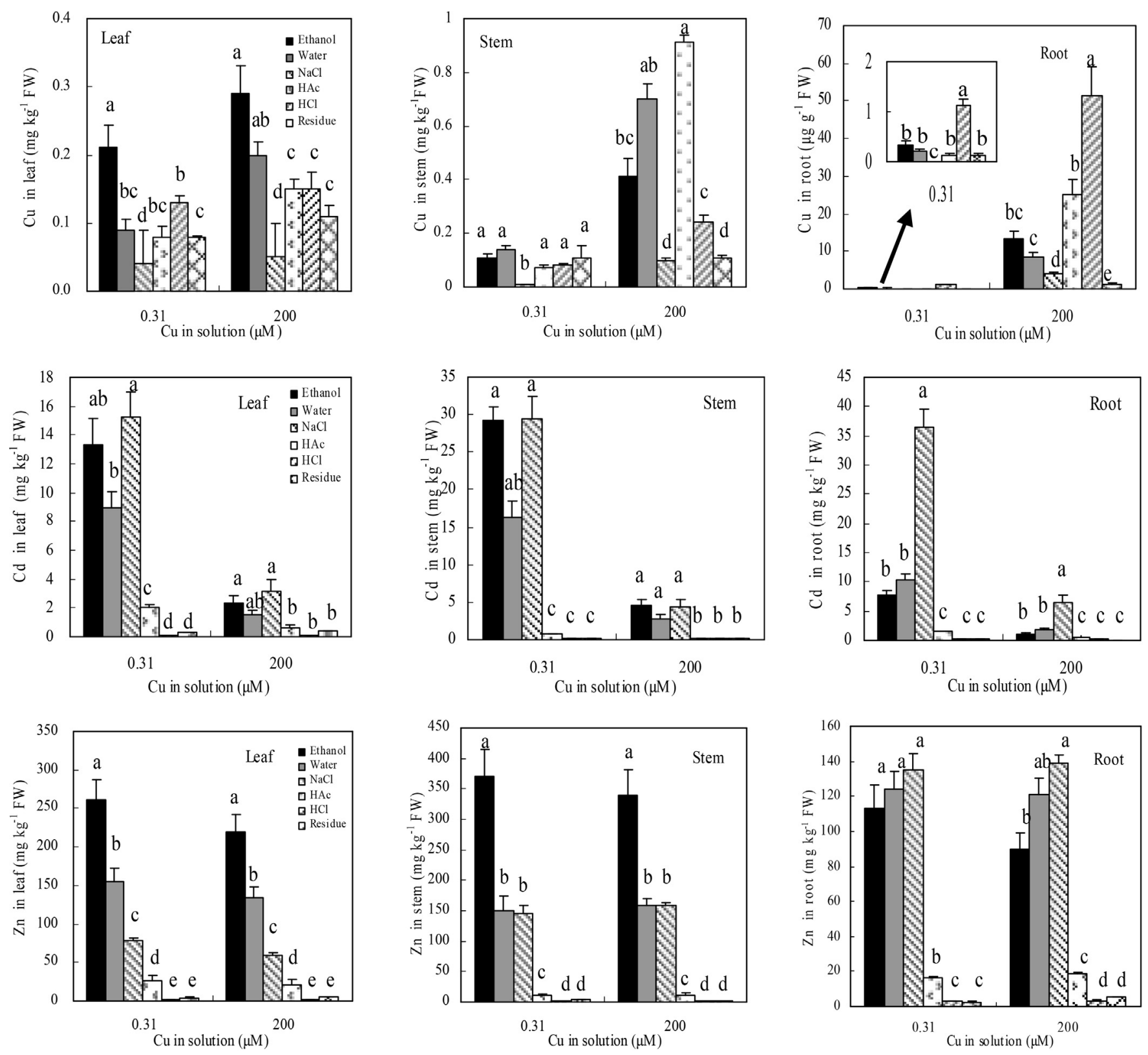

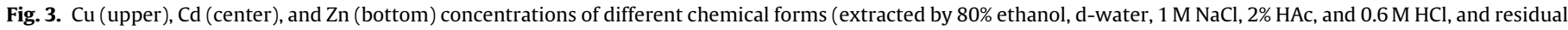

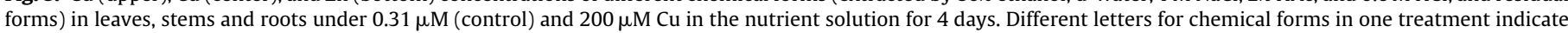
significant difference from each other $(P<0.05)$. Data presented are mean \pm standard error $(n=4)$.
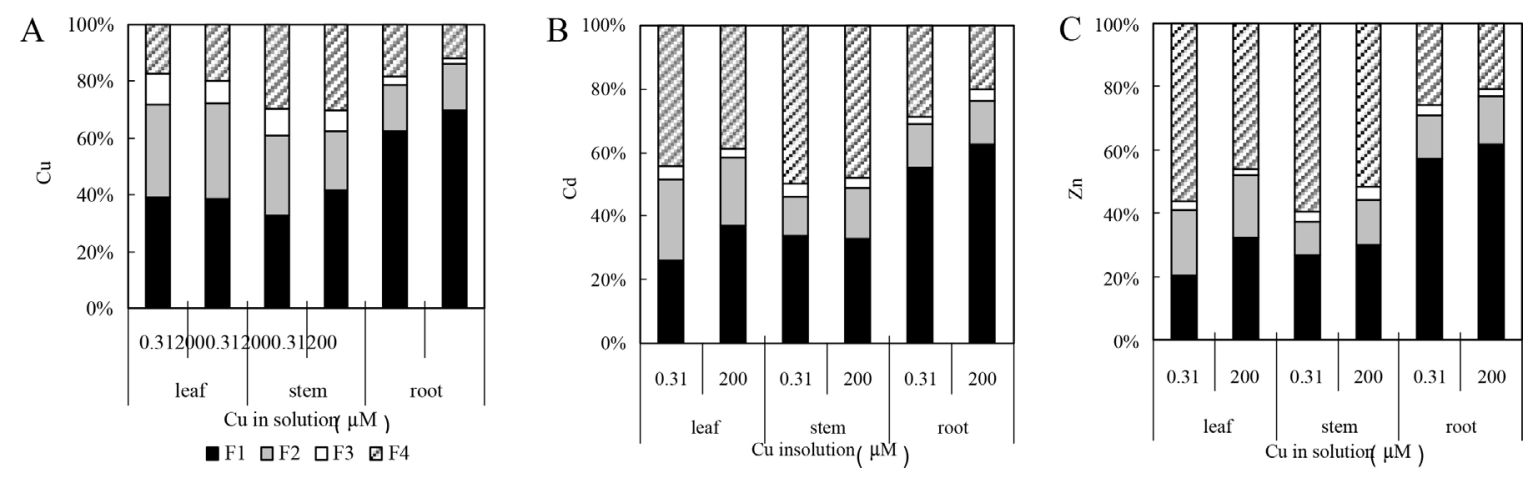

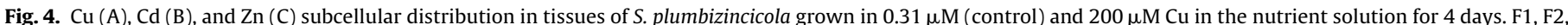

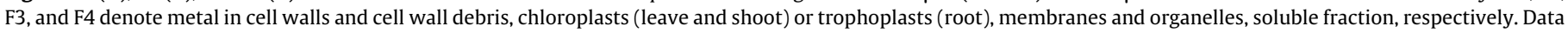
presented are mean \pm standard error $(n=4)$. 

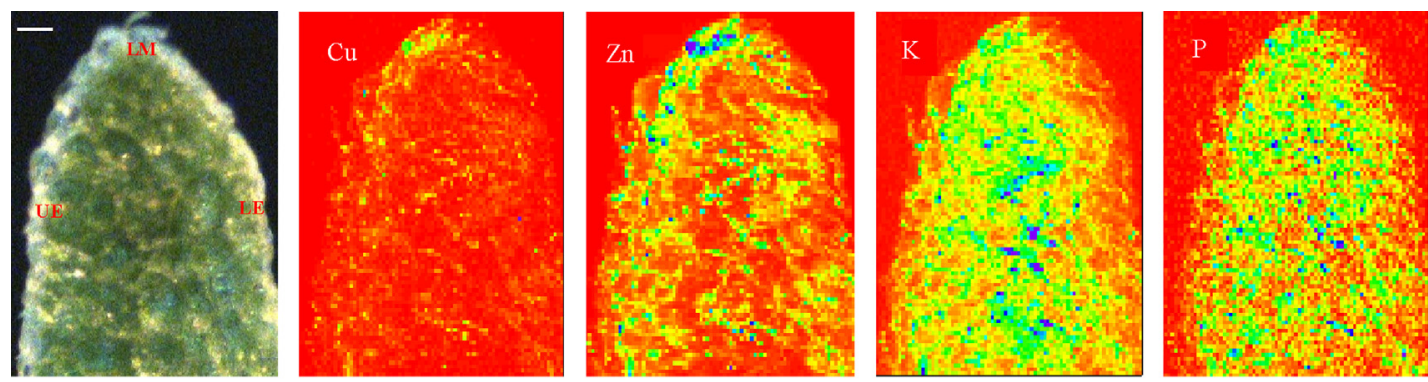

Microscope (A) $0.31 \mu \mathrm{M} \mathrm{Cu}_{\mathrm{Min}}{ }_{\mathrm{Max}}$
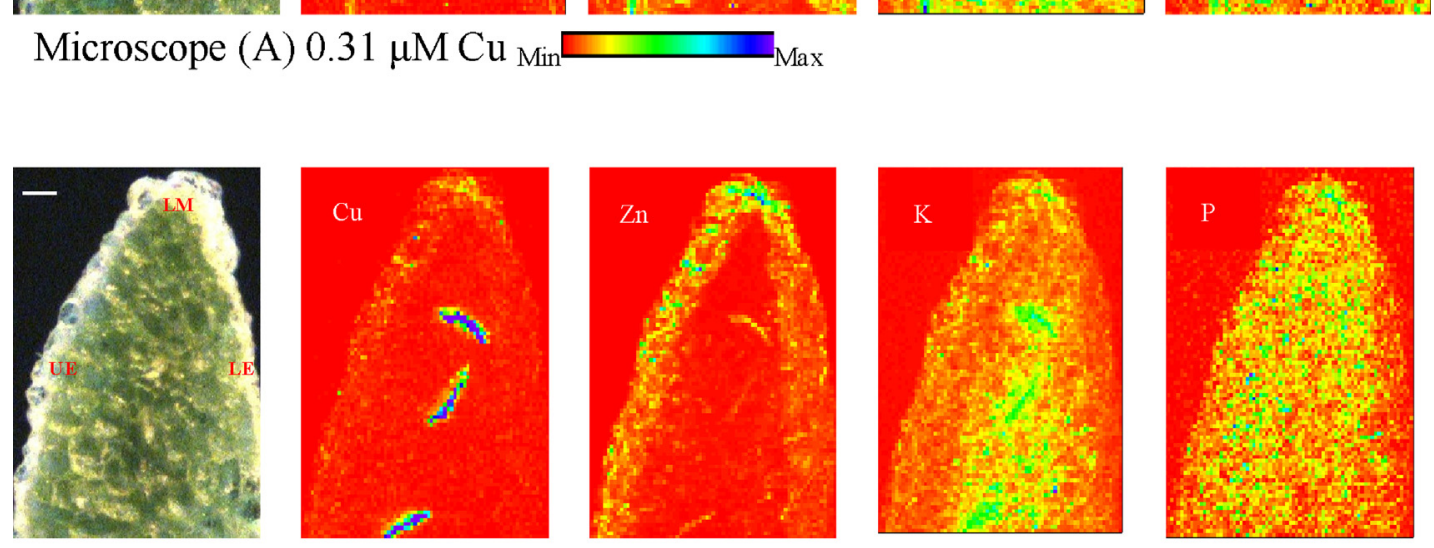

\section{Microscope (B) $200 \mu \mathrm{M} \mathrm{Cu}$ Min ${ }_{\text {Max }}$}

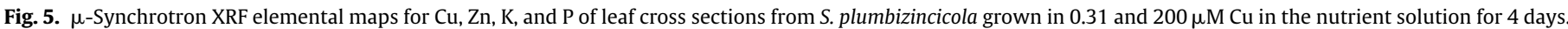

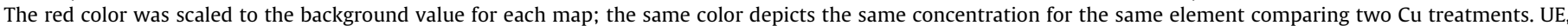
upper epidermis; LE, lower epidermis; and LM, leaf margin. Scale bar, $100 \mu \mathrm{m}$.

on the plasma membrane and these may have been connected with the plasmolysis.

\section{Discussion}

\subsection{Effects of copper on S. plumbizincicola and plant detoxification}

Copper is an essential plant micronutrient that can promote growth at low concentrations in the growth medium but can be potentially toxic at high concentrations. In the present study $5-50 \mu \mathrm{M} \mathrm{Cu}$ in the nutrient solution did not increase plant leaf biomass significantly (Table 1 ), perhaps indicating that the $\mathrm{Cu}$ in the unamended solution was adequate for plant growth. A previous study found that a $3.61 \mathrm{mg} \mathrm{kg}^{-1} \mathrm{Cu}$ in soil inhibited S. plumbizincicola growth and addition of $\mathrm{Cu}$ to the soil increased the biomass significantly [23]. However, $100 \mu \mathrm{M}$ or $200 \mu \mathrm{M}$ Cu in nutrient solution significantly inhibited S. plumbizincicola biomass (Table 1). Copper concentrations in normal plants without toxicity symptoms vary with plant species, with an average $\mathrm{Cu}$ concentration in the leaves of $10 \mathrm{mg} \mathrm{kg}^{-1}$ and ranging from 5 to $20 \mathrm{mg} \mathrm{kg}^{-1}$ [12]. In $\mathrm{Cu}$ accumulator or tolerant plants the $\mathrm{Cu}$ concentration in the shoots can be $>1000 \mathrm{mg} \mathrm{kg}^{-1}$ [24]. In the $\mathrm{Cd} / \mathrm{Zn}$ hyperaccumulator S. plumbizincicola the $\mathrm{Cu}$ concentrations can be 37.1 , 30.9 , and $771 \mathrm{mg} \mathrm{kg}^{-1}$ in leaves, stems, and roots, respectively, without toxicity symptoms after growth for 14 days in nutrient solution with $50 \mu \mathrm{M} \mathrm{Cu}$ (Fig. 1). This foliar Cu concentration is higher than the critical toxicity level of $\mathrm{Cu}$ for vascular plants in general, $15-20 \mathrm{mg} \mathrm{kg}^{-1}$ [25], and is similar to that of the muchstudied Cd/Zn hyperaccumulator T. caerulescens exposed to $10 \mu \mathrm{M}$ $\mathrm{Cu}$ for 8 weeks, but with $T$. caerulescens showing significant toxicity [26]. Although S. plumbizincicola had a high tolerance to $\mathrm{Cu}$, when the $\mathrm{Cu}$ concentration in the nutrient solution was as high as 100 or $200 \mu \mathrm{M}$, it showed substantial toxicity and decrease in biomass (Table 1).

Root is the one plant organ that has direct contact with $\mathrm{Cu}$ in the growth medium. Exposed to excessive $\mathrm{Cu}$ in the growth medium, the root might be the first part of the plant to experience toxicity and to exhibit symptoms. After four days' exposure to $200 \mu \mathrm{M} \mathrm{Cu}$ S. plumbizincicola roots displayed toxicity symptoms and exuded white organic materials and this may have been associated with attempts to control Cu availability in the rhizosphere. This function of root exudation of organic matters to decrease Mn availability in the rhizosphere of ryegrass (Lolium perenne L.). was also found with increasing Mn concentration in nutrient solution [27]. Transmission electron micrographs indicate that the first toxicity symptom in root cells may be plasmolysis (Fig. 6D). The Cu concentration in leaves was very high ( $56 \mathrm{mg} \mathrm{kg}^{-1}$ ) after four days' exposure to $200 \mu \mathrm{M} \mathrm{Cu}$ and this had a marked influence on the chloroplasts. Compared to the control, starch accumulation in the chloroplasts of leaves exposed to $\mathrm{Cu}$ were fewer and smaller and with disorganized thylakoids (Fig. 6A and B). This decrease in starch has also been observed in soybean leaf cells after exposure to excessive $\mathrm{Cu}$ [28]. Some studies have shown significant increases in starch in A. thaliana and cucumber plants exposed to excessive $\mathrm{Cu}[29,30]$. Accumulation or decrease in starch may result from a balance between synthesis and utilization or translocation. In our study a decrease in synthesis and fast assimilation may both have occurred but the former was clearly indicated by the disordered thylakoids which would have undermined photosynthesis.

Metal distribution in the plant and its sub-cellular distribution and chemical speciation can reflect plant detoxification mechanisms. For the metal subcellular distribution plant usually bind most of metal to the cell wall or accumulate metal in the vacuoles instead of in high active part of cell (e.g. organelles), on the other hand, for metal chemical forms, the metal fractions extracted by $80 \%$ ethanol and d-water usually have higher migration and 

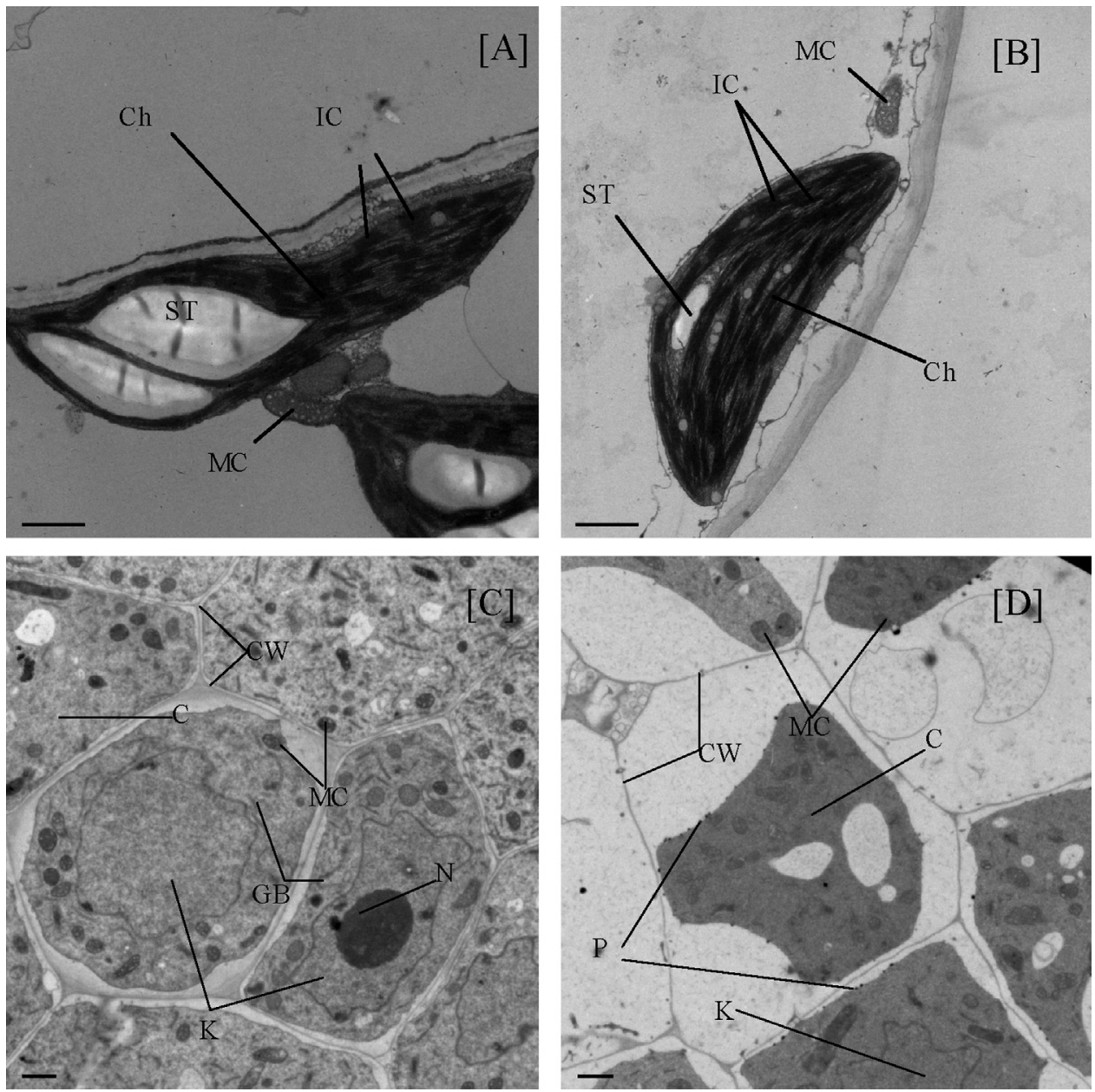

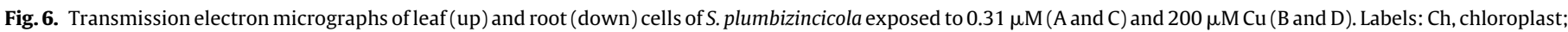

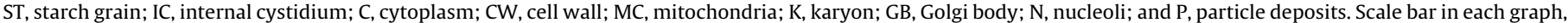
$1 \mu \mathrm{m}$.

toxicity than the metal extracted by $2 \% \mathrm{HAc}$ and $0.6 \mathrm{M} \mathrm{HCl} \mathrm{[15].} \mathrm{In}$ terms of the whole plant $\mathrm{Cu}$ accumulated mainly in the roots when exposed to excessive $\mathrm{Cu}$ (Figs. 1 and 2), indicating that S. plumbizincicola is a $\mathrm{Cu}$-excluder [31]. Immobilization of $\mathrm{Cu}$ in the roots and restrained $\mathrm{Cu}$ translocation to the shoot is a type of $\mathrm{Cu}$ detoxification mechanism. At the subcellular level, root $\mathrm{Cu}$ was mainly present in the cell walls, representing $>60 \%$ in both treatments (Fig. 4). Furthermore, chemical extraction results show that $65 \%$ and $75 \% \mathrm{Cu}$ occurred as $\mathrm{Cu}$-oxalate (extracted by $0.6 \mathrm{M} \mathrm{HCl}$ ) and insoluble metal fractions including $\mathrm{MHPO}_{4}$ and $\mathrm{M}_{3}\left(\mathrm{PO}_{4}\right)_{2}$ (extracted by $2 \% \mathrm{HAc}$ ) in the roots of the control and $\mathrm{Cu}$ treatments respectively (Fig. 3). Mijovilovich et al. [26] also found a strong metal-metal contribution to $\mathrm{Cu}-\mathrm{EXAFS}$ spectra in $T$. caerulescens and regarded this as likely to be $\mathrm{Cu}$-oxalate and $\mathrm{Cu}$ oxides. In stems and leaves of $S$. plumbizincicola insoluble $\mathrm{Cu}$-phosphate increased much more than did $\mathrm{Cu}$-oxalate compared to the control, perhaps indicating that insoluble $\mathrm{Cu}$-phosphate had an important role in detoxification of stems and leaves (Fig. 3). Moreover, dark deposits on root cell membranes were found in the $200 \mu \mathrm{M}$ Cu treatments (Fig. 6). Similar deposits at cell walls or in vacuoles have also been found in other studies $[28,32]$. These deposits might be a form of chelate between the toxic metal and organic acids acting as a response to metal toxicity [33]. These results indicate that $\mathrm{Cu}$ immobilization in cell walls and fixation as insoluble forms in cells may be cellular level detoxification mechanisms in S. plumbizincicola.

\subsection{Effect of $\mathrm{Cu}$ on $\mathrm{Cd}$ and $\mathrm{Zn}$ uptake and translocation in $\mathrm{S}$. plumbizincicola}

In general, metals are uptake by the plant roots, delivered to the xylem, and transported and unloaded into storage parts such as the leaves. Interactions among metals can occur during these processes. Interactions might include competition for metal transporters during membrane transport where one transporter can carry different metals or disturbance of normal plant physiological functions affecting the uptake or translocation of other metals in the plant [7,13]. 5-50 $\mu \mathrm{M}$ Cu had no significant effect on plant $\mathrm{Cd}$ or $\mathrm{Zn}$ uptake or translocation compared to the control. This suggests that the transporters for $\mathrm{Cd}$ and $\mathrm{Zn}$ had high selective affinities or that the $\mathrm{Cd}$ and $\mathrm{Zn}$ transporter(s) were different from the $\mathrm{Cu}$ transporter(s) and this may explain why $S$. plumbizincicola is a hyperaccumulator of only Cd and Zn. However, 100 or $200 \mu \mathrm{M}$ $\mathrm{Cu}$ led to clear inhibition of $\mathrm{Cd}$ and $\mathrm{Zn}$ uptake (Figs. 1 and 2). Plants exposed to $200 \mu \mathrm{M}$ Cu for $14 \mathrm{~d}$ had significantly lower leaf and stem $\mathrm{Zn}$ and $\mathrm{Cd}$ concentrations than the controls, but after exposure for 4 days this inhibition occurred only in the leaves for $\mathrm{Zn}$. The different effects of different times of exposure to $\mathrm{Cu}$ on the $\mathrm{Zn}$ concentrations in the stems are easy to understand and illustrate. Long exposure times disrupt physiological functions such as photosynthesis and transpiration which in turn influence energy metabolism involved in metal transfer processes across membranes and in the xylem. 
Interestingly, $200 \mu \mathrm{M}$ Cu concentrations significantly lowered $\mathrm{Cd}$ concentrations in roots but had no effect on $\mathrm{Zn}$ after both short and long exposure times to $\mathrm{Cu}$ (Figs. 1 and 2). Cadmium is not essential to plants and studies on different $\mathrm{Cd}$ hyperaccumulator species have indicated that $\mathrm{Cd}$ uptake by roots and its transport to the xylem is by the symplastic pathway [34-36]. If this pathway also applies to $\mathrm{Cd}$ in S. plumbizincicola, high $\mathrm{Cu}$ concentrations would affect $\mathrm{Cd}$ transport across membranes. In addition, as discussed above, the formation of insoluble $\mathrm{Cu}$ phosphate is one the detoxification mechanisms of S. plumbizincicola and this deposition could affect ATP metabolism. Furthermore, plasmolysis in root cells could also physically disturb the transport of $\mathrm{Cd}$ across membranes (Fig. 6D). Although these mechanisms might also apply to $\mathrm{Zn}$, root $\mathrm{Zn}$ uptake showed no significant change from the control under the influence of $200 \mu \mathrm{M} \mathrm{Cu}$. This indicates that $\mathrm{Zn}$ and $\mathrm{Cd}$ have different transporters based on changes in energy metabolism and plasmolysis having no effect on $\mathrm{Zn}$ membrane transport or $\mathrm{Zn}$ and Cd having different transport pathway in the roots of $S$. plumbizincicola. There is some controversy as to whether $\mathrm{Zn}$ transport in the roots of the $\mathrm{Zn}$ hyperaccumulator $T$. caerulescens is mainly apoplastic or symplastic [37,38]. Moreover, metal subcellular distribution results show that the percentages of $\mathrm{Cd}$ and $\mathrm{Zn}$ in the cell walls of roots and leaves increased significantly (Fig. 4), possibly indicating that the symplastic pathway was inhibited for both $\mathrm{Zn}$ and $\mathrm{Cd}$ by high $\mathrm{Cu}$ concentrations. Although in this study the exact pathways of $\mathrm{Cd}$ and $\mathrm{Zn}$ in S. plumbizincicola roots cannot be fully elucidated, it is clear that $\mathrm{Cd}$ and $\mathrm{Zn}$ had different uptake mechanisms in the roots.

Unloading of metals to the leaves from the xylem and their subsequent storage is one of the mechanisms by which plants hyper-accumulate metals [39], and thus the concentration of metal in the leaves has a direct influence on the function of hyperaccumulators and on the practice of phytoremediation. Four days of $200 \mu \mathrm{M} \mathrm{Cu}$ treatment induced significantly lower Cd and Zn concentrations in the leaves compared to the control with no significant difference from plant background concentrations (Fig. 2). This suggests that $\mathrm{Cu}$ restrained $\mathrm{Cd}$ and $\mathrm{Zn}$ translocation and accumulation in S. plumbizincicola leaves. The vascular bundles include the veins where metals are unloaded from the xylem to other leaf cells and are the source of metals in the leaves. The XRF maps show considerable $\mathrm{Cu}$ accumulation in the leaf veins (Fig. 5B Cu) and chemical extraction shows that insoluble $\mathrm{Cu}$ phosphate increased significantly in both stems and leaves (Fig. 3). This indicates that an insoluble $\mathrm{Cu}$ complex deposited in the leaf veins can restrain the metabolism of key transporters or enzymes responsible for $\mathrm{Cd}$ and $\mathrm{Zn}$ unloading from the xylem to the leaves. However, the further investigations are required to determine how $\mathrm{Cu}$ influences this process. This information would help us to understand the mechanism of Cd/Zn accumulation by S. plumbizincicola in terms of metal unloading from stems to leaves.

\section{Conclusions}

Copper at $0.31-50 \mu \mathrm{M}$ had no significant effect on the growth or $\mathrm{Cd}$ or $\mathrm{Zn}$ uptake and accumulation of S. plumbizincicola but 100 or $200 \mu \mathrm{M}$ Cu showed inhibition of metal uptake by induction of plasmolysis in the root cells and damage to chloroplast structure. Moreover, S. plumbizincicola absorbed $\mathrm{Cu}$ in its roots but restricted translocation to the shoots, fixed $\mathrm{Cu}$ in the cell walls, and complexed $\mathrm{Cu}$ in insoluble forms as its detoxification mechanisms. 100 or $200 \mu \mathrm{M}$ Cu concentrations exerted different effects on $\mathrm{Cd}$ and $\mathrm{Zn}$ uptake by the roots and this indicates that the $\mathrm{Cd} / \mathrm{Zn}$ hyperaccumulator had different uptake mechanisms for $\mathrm{Cd}$ and $\mathrm{Zn}$. However, $200 \mu \mathrm{M}$ Cu restrained unloading of both $\mathrm{Cd}$ and $\mathrm{Zn}$ from the xylem to the leaves and this may be related to substantial $\mathrm{Cu}$ accumulation in the leaf veins. All these results indicate that effects of $\mathrm{Cu}$ need to be considered when using S. plumbizincicola to remediate soils polluted with $\mathrm{Cd}, \mathrm{Zn}$ and $\mathrm{Cu}$ and further investigation of the effects of $\mathrm{Cu} \mathrm{Cd}$ and $\mathrm{Zn}$ uptake and translocation mechanisms would help in understanding the mechanisms by which $S$. plumbizincicola hyperaccumulates both $\mathrm{Cd}$ and $\mathrm{Zn}$.

\section{Acknowledgments}

We thank the National Natural Science Foundation of China (40930739 and 41271326) and the National High Technology Research and Development (863) Program of China (2012AA06A204) for grant-aided support; we also thank the Shanghai Synchrontron Radiation Facility for supporting the microSXRF experiment.

\section{References}

[1] P. Iavazzo, D. Ducci, P. Adamo, M. Trifuoggi, A. Miglizzi, M. Boni, Impact of past mining activity on the quality of water and soil in the high Moulouya Valley (Morocco), Water, Air, \& Soil Pollution 223 (2012) 573-589.

[2] A. Izewska, E. Krzywy, C. Woloszyk, Evaluation of impact of fertilization with manure, municipal sewage sludge and compost prepared from sewage sludge on content of Mn, Zn, Cu, and Pb, Cd in light soil, Elementol Journal 14 (2009) $457-466$.

[3] P.K. Padmavathiamma, L. Li, Phytoremediation technology: hyperaccumulation metals in plants, Water, Air, \& Soil Pollution 184 (2007) $105-126$.

[4] G. Wu, H. Kang, X. Zhang, H. Shao, L. Chu, C. Ruan, A critical review on the bioremoval of hazardous heavy metals from contaminated soils: issues, progress, eco-environmental concerns and opportunities, Journal of Hazardous Materials 174 (2010) 1-8.

[5] H. Ali, E. Khan, M.A. Sajad, Phytoremediation of heavy metals-concepts and applications, Chemosphere 91 (2013) 869-881.

[6] R. Ghasemi, S.M. Ghaderian, U. Kramer, Interference of nickel with copper and iron homeostasis contributes to metal toxicity symptoms in the nickel hyperaccumulator plant Alyssum inflatum, New Phytologist 184 (2009) 566-580.

[7] H. Zhao, L. Wu, T. Chai, Y. Zhang, J. Tan, S. Ma, The effects of copper, manganese and zinc on plant growth and elemental accumulation in the manganesehyperaccumulator Phytolacca americana, Journal of Plant Physiology 169(2012) 1243-1252.

[8] K. Peng, C. Luo, W. You, C. Lian, X. Li, Z. Shen, Manganese uptake and interactions with cadmium in the hyperaccumulator Phytolacca americana L., Journal of Hazardous Materials 154 (2008) 674-681.

[9] R. Qiu, P. Thangavel, P. Hu, P. Senthilkumar, R. Ying, Y. Tang, Interaction of cadmium and zinc on accumulation and sub-cellular distribution in leaves of hyperaccumulator Potentilla griffithii, Journal of Hazardous Materials 186 (2011) 1425-1430

[10] C. Cosio, E. Martinoia, C. Keller, Hyperaccumulation of cadmium and zinc in Thlaspi caerulescens and Arabidopsis halleri at the leaf cellular level, Plant Physiology 134 (2004) 1-10.

[11] A. Papoyan, M. Pi ñeros, L.V. Kochian, Plant $\mathrm{Cd}^{2+} \mathrm{Zn}^{2+}$ status effects on root and shoot heavy metal accumulation in Thlaspi caerulescens, New Phytologist 175 (2007) 51-58

[12] D.E. Baker, J.P. Senef, Heavy metal in soils, in: B.J. Alloway (Ed.), Copper, Blackie Academic and Professional, London, 1995, pp. 179-205.

[13] I. Yruela, Copper in plants: acquisition, transport and interactions, Functional Plant Biology 36 (2009) 409-430.

[14] U. Najeeb, G. Jilani, S. Ali, Insights Sarwar, L. Xu, W. Zhou, Insights into cadmium induced physiological and ultra-structural disorders in juncus effusus L. and its remediation through exogenous citric acid, Journal of Hazardous Materials 186 (2011) 565-574

[15] X. Wang, Y. Liu, G. Zeng, L. Chai, X. Song, Z. Min, X. Xiao, Subcellular distribution and chemical forms of cadmium in Bechmeria nivea (L.) Gaud, Environmental and Experimental Botany 62 (2008) 389-395

[16] L. Wu, N. Li, Y. Luo, Phytoextraction of heavy metal contaminated soil by Sedum plumbizincicola under different agronomic strategies, in: Proceedings of the 5 th International Phytotechnology Conference, 2008, pp. 49-50.

[17] L. Liu, L. Wu, N. Li, Y. Luo, S. Li, Z. Li, C. Han, Y. Jiang, P. Christie, Rhizosphere concentrations of zinc and cadmium in a metal contaminated soil after repeated phytoextraction by Sedum plumbizincicola, International Journal of Phytoremediation 13 (2011) 750-764

[18] L. Wu, Z. Li, C. Han, L. Liu, Y. Teng, X. Sun, C. Pan, Y. Huang, Y. Luo, P. Christie, Phytoremediation of soil contaminated with cadmium, copper and polychlorinated biphenyls, International Journal of Phytoremediation 14 (2012) 570-584.

[19] L. Wu, Z. Li, I. Akahane, L. Liu, C. Han, T. Makino, Y. Luo, P. Christie, Effects of organic amendments on $\mathrm{Cd}, \mathrm{Zn}$ and $\mathrm{Cu}$ bioavailability in soil with repeated phytoremediation by Sedum plumbizincicola, International Journal of Phytoremediation 14 (2012) 1024-1038. 
[20] H. Peng, P.M.H. Kroneck, K. Hendrik Toxicity, Deficiency of copper in Elsholtzia splendens affect photosynthesis biophysics, pigments and metal accumulation, Environmental Science \& Technology 47 (2013) 6120-6128.

[21] F. Wu, J. Dong, Q. Qian, G. Zhang, Subcellular distribution and chemical form of $\mathrm{Cd}$ and $\mathrm{Cd}-\mathrm{Zn}$ interaction in different barley genotypes, Chemosphere 60 (2005) 1437-1446.

[22] H.J. Weigel, H.J. Jäger, Subcellular distribution and chemical form of cadmium in bean plants, Plant Physiology 65 (1980) 480-482.

[23] Z. Li, J. Ren, B. Yang, S. Wang, L. Wu, Y. Luo, Effect of copper on the growth and Zn and Cd accumulation of Sedum plumbizincicola, Soils 44 (2012) 626-631 (in Chinese).

[24] S.V. Sahi, M. Israr, A.K. Srivastava, J.L. Gardea-Torresdey, J.G. Parsons, Accumulation, speciation and cellular localization of copper in Sesbania drummondii, Chemosphere 67 (2007) 2257-2266.

[25] A.M.B. Pahlsson, Toxicity of heavy metals $(\mathrm{Zn}, \mathrm{Cu}, \mathrm{Cd}, \mathrm{Pb})$ to vascular plants: a literature review, Water, Air, \& Soil Pollution 47 (1989) 287-319.

[26] A. Mijovilovich, B. Leitenmaier, W. Meyer-Klauche, P.M.H. Kroneck, B. Gotz, H. Kupper, Complexation and toxicity of copper in higher plants. II. Different mechanisms for copper versus cadmium detoxification in the copper-sensitive cadmium/zinc hyperaccumulator Thlaspi caerulescens (Ganges ecotype), Plant Physiology 151 (2009) 715-731.

[27] M.D. Mora, A. Rosas, A. Ribera, Z. Rengel, Differential tolerance to Mn toxicity in perennial ryegrass genotypes: involvement of antioxidative enzymes and root exudation of carboxylates, Plant Soil 320 (2009) 79-89.

[28] M. Bernal, P. Sanchez-Testillano, M.D. Risueno, I. Yruela, Excess copper induces structural changes in cultured photosynthetic soybean cells, Functional Plant Biology 33 (2006) 1001-1012.

[29] M. Wójcik, A. Tukiendorf, Response of wild type of Arabidopsis thaliana to copper stress, Biologia Plantarum 46 (2003) 79-84.

[30] B. Alaoui-Sossé, P. Genet, F. Vinit-Dunand, M.L. Toussaint, D. Epron, P.M. Badot, Effect of copper on growth in cucumber plants (Cucumis sativus) and its relationships with carbohydrate accumulation and changes in ion contents, Plant Science 166 (2004) 1213-1218.

[31] S. Rossini Oliva, M.D. Mingorance, B. Valdés, E.O. Leidi, Uptake, localisation and physiological changes in response to copper excess in Erica andevalensis, Plant Soil 328 (2010) 411-420.

[32] P.M. Kopittke, C.J. Asher, F.P.C. Blamey, N.W. Menzies, Toxic effects of $\mathrm{Cu}^{2+}$ on growth, nutrition, root morphology, and distribution of Cu in roots of Sabi grass, Science of the Total Environment 407 (2009) 4616-4621.

[33] W.E. Rauser, Structure and function of metal chelators produced by plants: the case for organic acids, amino acids, phytin, and metallothioneins, Cell Biochemistry and Biophysics 31 (1999) 19-48.

[34] L. Lu, S. Tian, X. Yang, T. Li, Z. He, Cadmium uptake and xylem loading are active processes in the hyperaccumulator Sedum alfredii, Journal of Plant Physiology 166 (2009) 579-587.

[35] D. Ueno, T. Iwashita, F. Zhao, J. Ma, Characterization of Cd translocation and identification of the $\mathrm{Cd}$ form in xylem sap of the $\mathrm{Cd}$ hyperaccumulator Arabidopsis halleri, Plant and Cell Physiology 49 (2008) $540-548$.

[36] J. Xing, R. Jiang, D. Ueno, J. Ma, H. Schat, S.P. McGrath, F. Zhao, Variation in rootto-shoot translocation of cadmium and zinc among different accessions of the hyperaccumulators Thlaspi caerulescens and Thlaspi praecox, New Phytologist 178 (2008) 315-325.

[37] W.H.O. Ernst, A.G.L. Assuncao, J.A.C. Verkleij, H. Schat, How important is apoplastic zinc xylem loading in Thlaspi caerulescens, New Phytologist 155 (2002) 4-5.

[38] P.J. White, S.N. Whiting, A.J.M. Baker, M.R. Broadley, Does zinc move apoplastically to the xylem in roots of Thlaspi caerulescens, New Phytologist 153 (2002) 201-207.

[39] M.D. Guimarães, J.L. Gustin, D.E. Salt, Reciprocal grafting separates the roles of the root and shoot in zinc hyperaccumulation in Thlaspi caerulescens, New Phytologist 184 (2009) 323-329. 